\title{
LA CÚPULA DE LA BASÍLICA DE LA VIRGEN DE LOS DESAMPARADOS DE VALENCIA (I): EL ÁMBITO DE LA GLORIA
}

\author{
POR \\ RAFAEl GARCíA MAHÍQUES \\ Universidad de Valencia
}

Estudio iconográfico de los frescos de la cúpula de la Basílica de la Virgen de los Desamparados de Valencia, obra de Antonio Palomino realizada entre 1701 y 1704. Aproximación a un análisis del ámbito de la Gloria celestial. Aquí la Virgen aparece como reina e intercesora ante el Trono de Gracia, en donde, de acuerdo con la tradición iconográfica, se incluye a San Juan Bautista y los arma Christi portados por ángeles. En torno a este núcleo se disponen los bienaventurados, agrupados bajo el criterio de la Letanía Lauretana, en la cual María es invocada con los títulos de Reina de los Ángeles, de los Patriarcas, Profetas, Apóstoles, Mártires, Confesores, Vírgenes y de Todos los Santos. Este artículo tiene continuidad con otro titulado: "La Cúpula de la Basílica de la Virgen de los Desamparados de Valencia (y II): El ámbito Histórico-Alegórico", con el cual se completa el estudio.

Palabras Clave: Iconografía, Iconología, Gloria, Antonio Palomino, Basílica Virgen Desamparados, María intercesora, Letanía lauretana, Trinidad, Trono de Gracia, Arma Christi, Bienaventurados, Ángeles, Patriarcas, Profetas, Apóstoles, Mártires, Confesores, Vírgenes, Santos, Doctores de la Iglesia, Órdenes religiosas.

Iconographical study of the frescoes of the cupola of the Basílica de la Virgen de los Desamparados of Valencia, a work by Antonio Palomino, painted between 1701 and 1704. It is an approach to the analysis of the scope of the Celestial Glory. Here the Virgin appears as Queen and intercessor before the Throne of Grace, where, according to the iconographical tradition, St John The Baptist is included, and the arma Chris$t i$ carried by angels. Around this nucleus they are arranged the Fortunate, grouped by the criterion of the Litany of Loreto, in which Mary is invoked with the titles of Queen of the Angels, of the Patriarchs, Prophets, Apostles, Martyrs, Confessors, Virgins and All the Saints. This article keeps continuity with another one previous titled. "La Cúpula de la Basílica de la Virgen de los Desamparados de Valencia (y II): El ámbito Histórico-Alegórico", with which the study is completed.

KeY words: Iconography, Iconology, Glary, Antonio Palomino, Basílica Virgen Desamparados, Mary intercessor, Litany of Loreto, Trinity, Throne of Grace, Arma Christi, Fortunate, Angels, Patriarchas, Prophets, Apostles, Martyrs, Confessors, Virgins, Saints, Doctors of the Church, Religions Orders. 
La pintura mural de la bóveda de la R. Basílica de la Virgen de los Desamparados de Valencia (fig. 1), que milagrosamente ha llegado intacta a nuestros días, es una obra excepcional y con la cual su creador, el pintor Antonio Palomino, puede con justicia compartir la gloria con los grandes artistas inmortales. Estamos ante una de las cumbres del barroco universal, que bien merece un estudio iconográfico en profundidad, algo que ha podido llevarse a cabo en el marco de la restauración de este conjunto ${ }^{1}$.

Antonio Palomino, cuando proyecta la decoración pictórica de la bóveda de la Basílica de la Virgen de los Desamparados de Valencia, define su concepto como "panegírico mudo de las glorias, excelencias y prerrogativas de esta soberana Señora (...) a que principalmente ha de dirigirse la retórica silenciosa de esta oración delineada", algo que a cualquier admirador del Barroco no deja de sorprender, por no decir también decepcionar. Probablemente hubieran sido preferibles otros calificativos diferentes a los de "panegírico mudo" o "retórica silenciosa", no precisamente por no tratarse de ambas cosas, que lo son plenamente en sentido "racional", mas no en lo "poético", y además, por encima de todo, se echa de menos lo que realmente hay allí pintado: el Cielo. En tal sentido, convendría traer a la memoria la descripción que Giovanni Bellori hizo de la cúpula de la iglesia romana de Sant'Andrea della Valle, pintada por Lanfranco unos 70 años antes que lo hiciera aquí Palomino ${ }^{2}$. Bellori evoca el mismo Cielo cuando describe la recepción de María, en su Asunción, por la Trinidad entre coros de ángeles ${ }^{3}$, y se expresa así:

"En intervalos alternados de aire y luz, se abre el paraíso de sonrosadas nubes radiantes con una alegre y armoniosa gloria de ángeles que se mueven hacia al centro en coros de jóvenes y niños sentados e inmersos en un resplandor centelleante, emitiendo sonidos y cánticos con flautas, violas, tímpanos y otros diversos instrumentos musicales. (...) la dulzura del color nos hace oír la música celestial en el silencio de la pintura (...)"

Vemos que los conceptos pictóricos expresados por Lanfranco y por Palomino son bastante próximos: si allí es María recibida por la Trinidad entre los coros de ángeles, aquí se trata de María como intercesora ante la Trinidad entre todas las criaturas celestes. En el fondo ambas pinturas tienen en común el tratar de ajustarse a una representación del Cielo en todo su glorioso esplendor con ángeles y santos. Por eso causa extrañeza que Palomino refiera todo el conjunto pictórico de la Basílica como "panegírico mudo", mientras que Bellori perciba incluso la música de los coros angélicos. Ciertamente los escritos de Bellori y de Palomino son de diferente género, mientras el primero es un crítico el segundo no hace sino exponer un proyecto, pero ni ello justifica que el mismo pintor no se sienta inducido a percibir algo más que la "retórica silenciosa".

No obstante Palomino nos ha dejado en los frescos de la Basílica una obra absolutamente excepcional, con sus luces y sus desaciertos, una de las composiciones más excelsas del Barroco hispánico que lejos de constituir un "panegírico mudo", se trata, al contrario, de una ilusión muy viva y dinámica del Cielo en donde conviven en un mismo ámbito los santos y las personificaciones alegóricas de la retórica, algo por otro lado muy propio del Barroco y que recuerda el platónico Mundo de las Ideas en donde también tienen su auténtica ubicación las realidades abstractas.

Pero a pesar de la prosaica presentación que hace Palomino de su proyecto, su escrito es de gran importancia para la inteligencia de la obra. Es más, estamos ante la privilegiada situación en la que el mismo artista explica el significado de su pintura, su programa iconográfico, algo que ha ocurrido en contadas ocasiones a lo largo de la historia, lo que pone al historiador del arte ante la evidencia cierta acerca del contenido de lo expresado mediante la pintura, acostumbrados como estamos a la sutileza del leguaje ambiguo de las imágenes. También hay que decir que este testimonio es muy desigual en sus precisiones, unas veces muy parco y sin entrar en detalles -en especial cuando se ocupa de la Gloria-, en otras en cambio bastante explícito. En todo caso, como iremos comprobando, parece tratarse de la exposición de su proyecto inicial, sin haber tenido en cuenta los cambios y matices que se fueron introduciendo durante la ejecución de la obra.

\footnotetext{
${ }^{1}$ El presente estudio está integrado en el proyecto: Recuperación integral de la Basílica de la Virgen de los Desamparados de Valencia, llevado a cabo por la Universidad Politécnica de Valencia, bajo la dirección de Ignacio Bosch ReIG (general) y Pilar RoIG PicAzo (pintura).

2 Está documentada entre 1701 y 1704 la intervención de Palomino en la Basílica.

3 Bellori, Giovanni Pietro, Le Vite de'Pittori, Scultori et Architetti Moderni, Roma, 1672, pp. 370 y ss.
} 
Es por ello que a la hora de acceder a este conjunto pictórico lo hayamos de hacer necesariamente guiados por este documento, sin que ello nos reste el necesario espíritu crítico que nos permita su mejor y más completa comprensión. Con este ánimo he acometido el presente estudio.

Dos advertencias previas más antes de entrar en los pormenores de este cielo. En primer lugar, Palomino es un pintor del Barroco, por tanto sus pinturas son retóricas, y retórica es también toda esta gloria celeste. Es decir, que la composición de la obra pictórica ha sido elaborada con la intención de componer un discurso visual basado en la semántica de la imagen. Todo esto implica y exige convencionalismo y rigor en la definición de las imágenes, pero Palomino es más bien parco y economiza los elementos definidores de éstas: los atributos. Esto resulta también comprensible, puesto que los atributos pueden entorpecer la libre expresividad mediante los gestos y otros recursos estéticos, y observando el estilo dinámico de Palomino se comprende aún más. Unido esto a que el discurso visual a través de la imagen por la propia naturaleza de ésta, ofrece siempre flancos imprecisos, el resultado es que en algún caso se dan ciertos problemas de identificación de imágenes.

En segundo lugar, el conjunto pictórico pretende ser una figuración de la inconmensurable Gloria celeste con todas sus criaturas. Palomino quiso disponer de una superficie completamente rasa justamente para poder expresar ordenadamente todo este inmenso concepto, lo que logró, como sabemos, gracias a la infra-bóveda de tabique que soporta sus pinturas. En este espacio se desenvuelven multitudes de criaturas que se pierden en el infinito entre nubes. Toda esta disposición requiere de una serie de recursos técnicos, entre los cuales quizás el más importante sea la definición de figuras complementarias cuyo estatuto ontológico no vaya más allá del simple anonimato. Será ello lo que explique, por ejemplo, que detrás del grupo de santos valencianos figuren dos cabezas de dos santas mártires portadoras de palma, o más arriba un grupo de mitrados en torno a un papa con capa pluvial y tiara que nos da la espalda, y lo mismo pudiera decirse de otros personajes que conversan en el grupo de los patriarcas vetero-testamentarios. En suma, debemos introducirnos en este cielo con mucha prudencia descriptiva y sobre todo sin la obsesión por identificar cualquier silueta con algún personaje, bien santo o bien simplemente personaje histórico célebre, como de hecho ya ha ocurrido ${ }^{4}$.

Hechas estas advertencias, podemos pasar ya a considerar detalladamente el conjunto. Su estructura es sencilla, ya que se compone de tres niveles: el Histórico, el Alegórico y la Gloria propiamente dicha. Los dos primeros están prácticamente unidos, tanto desde el punto de vista compositivo como semántico y ocupan el basamento de arquitectura fingida que recorre la base de la bóveda, el cual incorpora también las ventanas. El nivel Histórico se concentra en las tarjas o cartelas que contienen diversas escenas en grisalla, simulando relieves monocromos, alternándose azulados con dorados. Casi todos ellos se refieren a milagros de la Virgen, puestos en correspondencia con una cualidad de la Letanía Lauretana, la cual es expresada mediante las personificaciones que componen el nivel Alegórico. Por encima de todo, corre la Gloria celeste, que constituye el tercero de los niveles referidos y el primero del que nos vamos a ocupar, ya que iremos siguiendo el referido documento publicado por Palomino en su tratado Museo Pictórico o Escala Óptica ${ }^{5}$. En un próximo artículo, en estas mismas páginas, nos ocuparemos del ámbito histórico-alegórico.

En el ámbito de la Gloria, el artista introduce el tema fundamental: La Virgen de los Desamparados como intercesora de todo el género humano ante su Hijo. María como intercesora es uno de los argumentos esenciales de la mariología, que goza así mismo de una tradición iconográfica secular. Antonio Palomino,

\footnotetext{
4 Para este estudio, debo de agradecer la colaboración de Juan Antonio FerRER JUÁREZ, buen conocedor de la iconografía de los santos. Otras aproximaciones anteriores que necesariamente he tenido que consultar son, en primer lugar, la de Santiago Sebastián, "Iconografía de los frescos de la cúpula", en V Centenario advocación Mare de Déu dels Desemparats, Valencia, 1993, pp. 121 y ss. Es éste el primer estudio serio que se hace sobre el programa iconográfico, si bien la escasez de medios con que el prof. Sebastián contó en sus días hizo que cayese en algunos errores que hoy, gracias a la observación a corta distancia, puedan ser subsanados. También he consultado los estudios previos a la restauración de estas pinturas realizados por Joaquín EsPí, "Panegírico mudo de las glorias, excelencias y prerrogativas de esta Soberana Señora", en Estudios previos, inédito. Este estudio es sólo una aproximación que, ante los elementos más problemáticos del análisis iconográfico, no acierta en algunos y deja sin resolver otros, ni tampoco profundiza en la comprensión y el sentido del conjunto.

5 Sigo la ed. de Buenos Aires, Ed. Poseidón, 1944, t. II, pp. 314-321.
} 


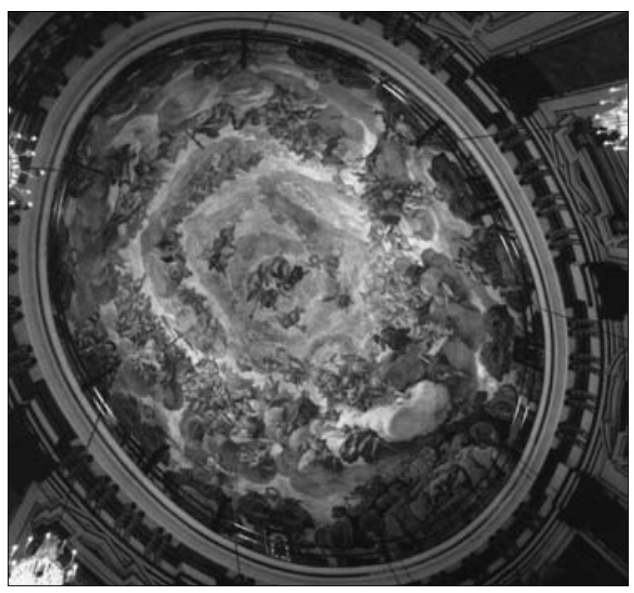

Fig. 1. Cúpula de la Basílica de la Virgen de los Desamparados.

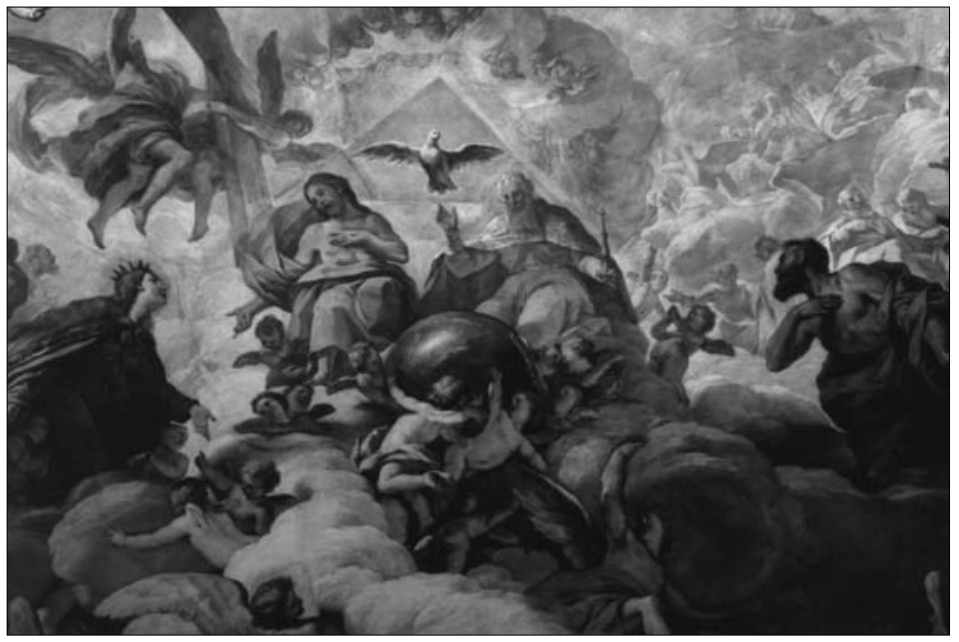

Fig. 2. María intercesora ante el Trono de Gracia.

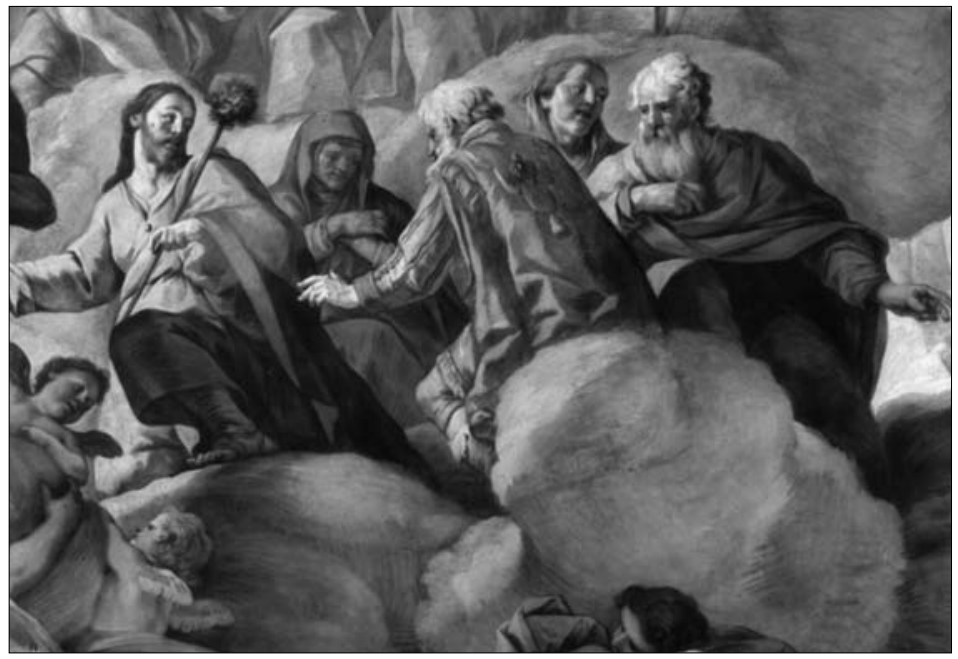

Fig. 3. La Santa Parentela. 
sin duda guiado por un mentor teológico ${ }^{6}$, de cuya personalidad no poseemos indicios para su identificación, ha entendido del siguiente modo esta solemne formulación teológica, que permite encajar la advocación de los Desamparados:

"Habiendo de ser la pintura de dicha bóveda un panegírico mudo de las glorias, excelencias y prerrogativas de esta soberana Señora, y especialmente de aquellas que más se adaptaren á el glorioso timbre de protectora de los Desamparados, que es el tema á que principalmente ha de dirigirse la retórica silenciosa de esta oración delineada: se pondrá en la parte superior á el retablo, y más directa a la vista, un hermoso trono de nubes, y ángeles, donde esté presidiendo la Trinidad santísima, ante cuyo supremo consistorio, y hácia la diestra del Hijo de Dios, según aquel verso: Astitit Regina à dextris tuis, \&c, se colocará esta soberana Reyna con Real corona, y con la vestidura bordada de oro, in vestita deaurato, sin que le falte el acompañamiento hermoso de las vírgenes: Adducentur Regi Vírgenes post eam. Y para expresar el atributo de protectora de los Desamparados, estará en acto de interceder por ellos a su hijo sacratísimo, que con grato semblante la atenderá, complacido de su ruego: Veni columba mea, \&c. ${ }^{7}$ Sub umbra alabarum (sic) tuarum protege me. ${ }^{8}$ Acompañará lo restante del casco superior de la bóveda el coro de los sagrados Apóstoles, los mas inmediatos á el trono: Sedebitis super sedes duodecim, iudicantes, \&c. ${ }^{9}$ Continuaran los Profetas, Patriarcas, Mártires, y Confesores, en que tendran su debido lugar los santos valencianos, como los más interesados en esta soberana prenda: interpolandose varias tropas de angeles en diferentes coros de música, demostrando á el mismo tiempo esta celestial comitiva los gloriosos timbres de ser esta Señora Reyna de los Angeles, de los Apóstoles, Profetas, Patriarcas, Vírgenes, Mártires, Confesores, y de todos los Bienaventurados, que todo conduce á el intento, pues esfuerza nuestra confianza, quando acredita la protección, la excelencia de quien la practica."

Palomino, por tanto, nos señala una serie de elementos ordenados jerárquicamente, cuyo eje lo constituye la imagen de María como Reina intercesora ante la Trinidad entre los diferentes coros de ángeles y de santos, tal como reza la propia Letanía Lauretana, el hilo argumental esencial que inspirara la semántica de esta bóveda, según iremos viendo. Esta letanía establece los coros de los bienaventurados con el siguiente orden: Reina de los Ángeles, Reina de los Patriarcas, Reina de los Profetas, Reina de los Apóstoles, Reina de los Mártires, Reina de los Confesores, Reina de las Vírgenes, Reina de todos los Santos. Veámoslo por partes:

I.- Madre intercesora. Esta parte se constituye como el fundamento o núcleo que rige y determina todo el conjunto (fig. 2). Palomino elige el sector que recae sobre el retablo y por tanto la parte "más directa a la vista" como lugar para su ubicación. En este punto la Trinidad, conformada como Sedes Gratiae, concentra en torno a sí una serie de elementos, algunos de ellos no reseñados por Palomino en su texto y que conviene ir precisando. El Trono de Gracia está ordenado de acuerdo con una disposición típicamente hispánica: el anciano Padre Eterno presenta como signo de la Gracia redentora a su Hijo, sentado a su derecha, que es Cristo Salvador quien muestra los estigmas de su pasión -con la llaga del costado en la izquierda, el lugar del corazón- y por encima de ambos un gran nimbo triangular que contiene la paloma del Espíritu Santo. La gran esfera del cosmos es sostenida por ángeles a los pies del trono.

Es esencial que no pase inadvertido el contexto conceptual de este "trono de nubes" -con palabras de Palomino- el cual no es otro que el de la Parusía, muy sabiamente manejado por el artista. No podía ser de otra forma, pues la figura de María, aquí coronada como Reina y como Mater desertorum -con las figuras de los Santos Inocentes a sus pies así como la azucena inclinada señalando hacia abajo ${ }^{10_{-}}$, en actitud de

\footnotetext{
6 El gerundio con que comienza este discurso: "Habiendo de ser la pintura de dicha bóveda...", delata, al menos de forma tácita, la existencia de un programa o al menos un argumento a desarrollar, impuesto por el comitente.

${ }^{7}$ Cant. 2, 14 .

${ }^{8}$ Sal. 16,8

${ }^{9}$ Mat. $19,28$.

10 No es este un signo casual. De acuerdo con la leyenda, la Virgen daba golpecitos con la azucena sobre el cristal de la urna que la contenía y eso era entendido como signo de la existencia de algún abandonado al que había que socorrer. De hecho así ocurrió con unos náufragos, según nos relata Garfis de la Cerda en un manuscrito hoy ilocalizado, pero consultado por Rodrigo Pertegás, J., Historia de la antigua y Real Cofradía de Nuestra Señora de los Inocentes, Mártires y Desamparados, de la venerada Imagen y de su capilla, Valencia, 1923, pp. 245-246.
} 


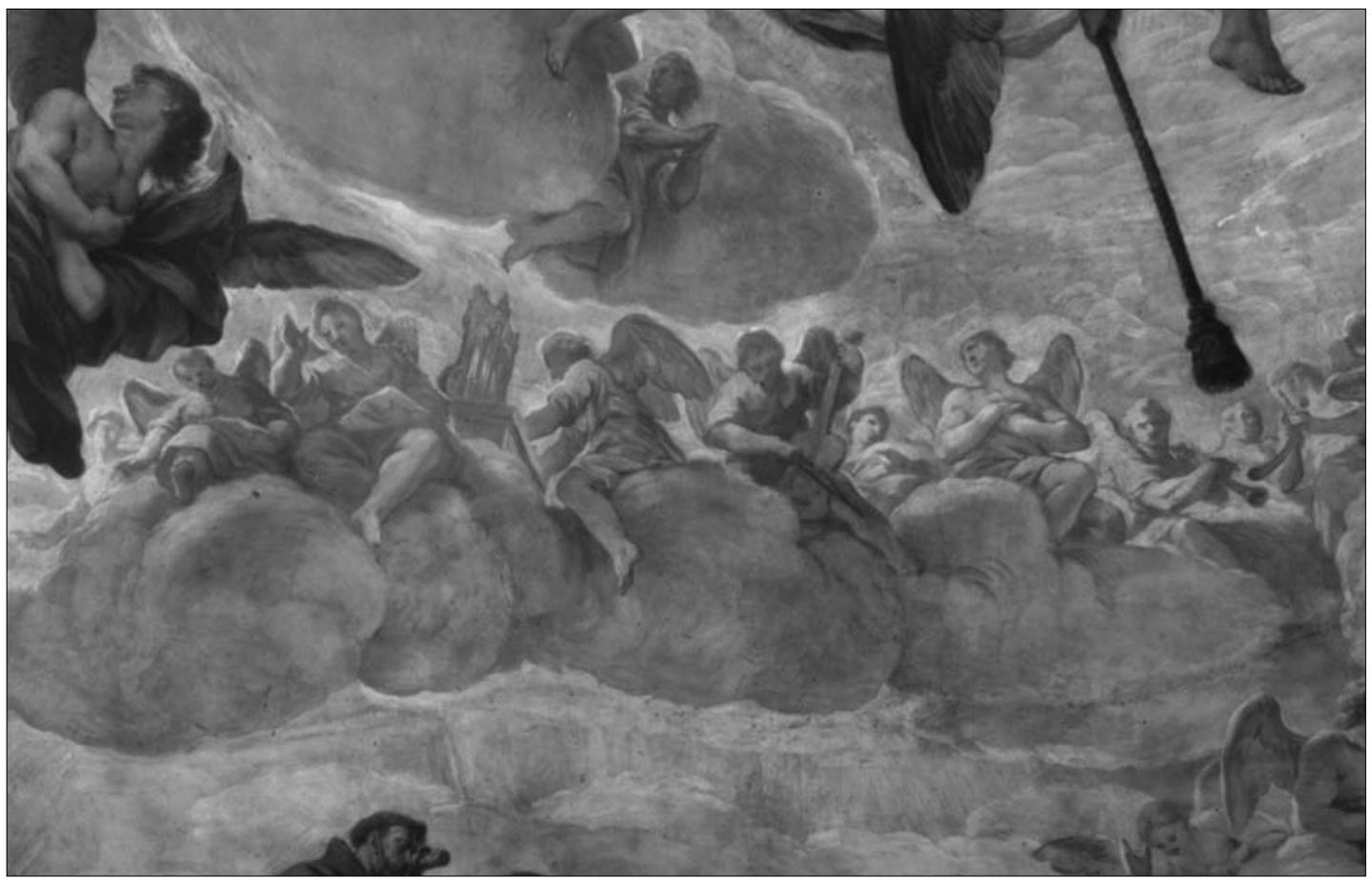

Fig. 4. Coro de Ángeles.

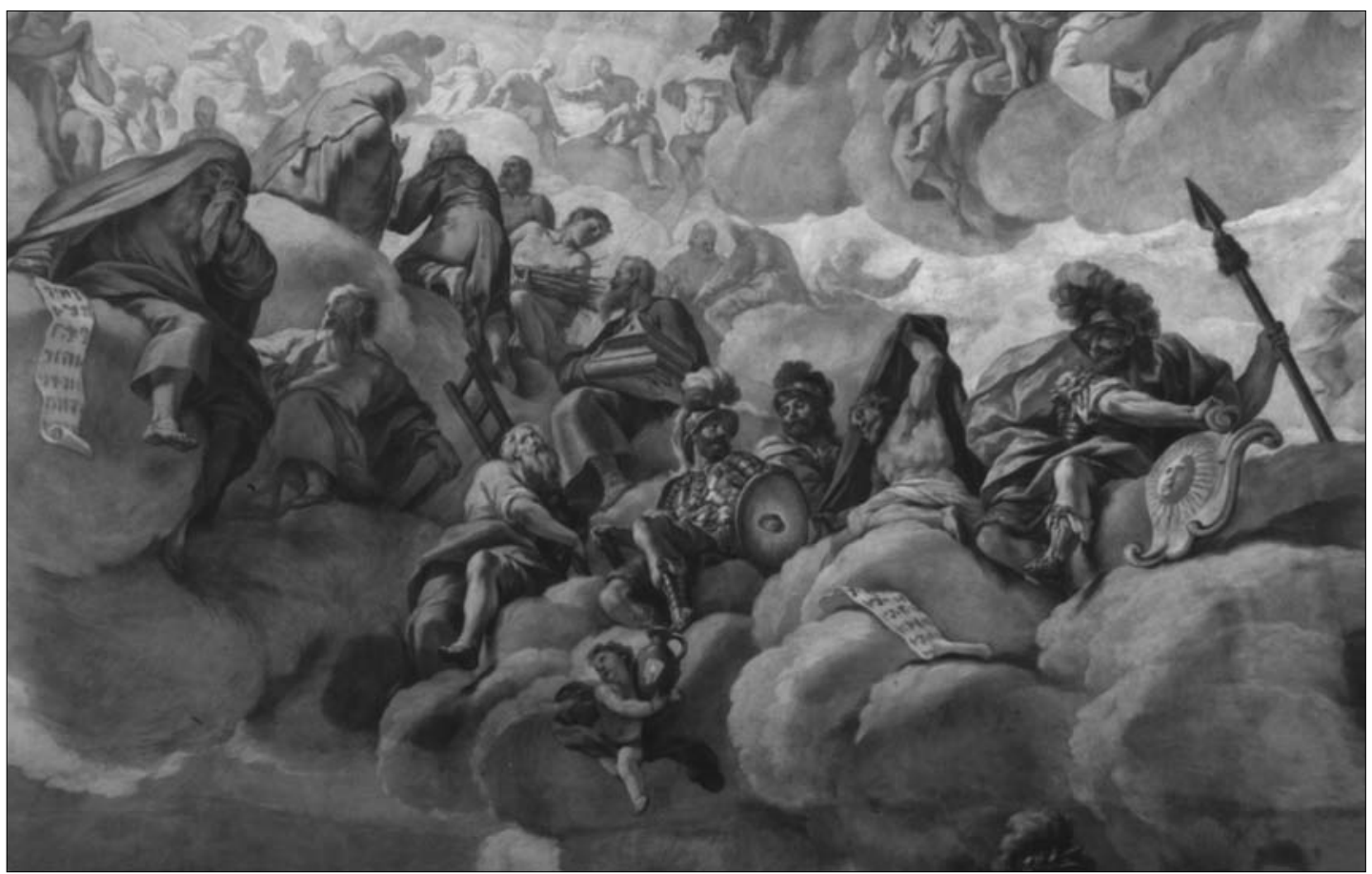

Fig. 5. Los Patriarcas.

AEA, LXXX, 317, ENERO-MARZO 2007, 67-83, ISSN: 0004-0428 
interceder ante su Hijo, constituye un tipo iconográfico que la tradición de las imágenes nos presenta asociada al contexto del Juicio Final. Tanto es así que el artista no ha podido siquiera eludir otros dos elementos indispensables en esta puesta en escena: San Juan Bautista y los ángeles portadores de los instrumentos de la pasión: los arma Christi. No obstante, estos elementos se integran de un modo muy discreto, casi como forzados por el rigor teológico, pero disponiéndose en un conjunto figurativo admirablemente resuelto por el artista quien ha demostrado gran capacidad de síntesis creativa; así San Juan Bautista, independientemente de su vigorosa factura pictórica, parece relegado a un papel un tanto secundario -las miradas de la Trinidad se centran en María, quien asume el liderazgo de esta función intercesora- y los arma Christi quedan reducidos a tres elementos: la cruz que portan los ángeles por detrás de la figura del Salvador, la corona de espinas y los clavos, mostrados también por sendos angelillos. Con todo, hay que destacar la originalidad de disponer la Trinidad en este contexto, ya que lo propio hubiera sido mostrar a María intercesora únicamente ante su Hijo, de acuerdo con la tradición convencional sobre el Juicio Final.

No obstante no podría decirse que, presentado de este modo, el concepto haya dado lugar a heterodoxia iconográfica alguna. Además, en un mayor alarde de composición iconográfica, Palomino ha sabido integrar con mucha perspicacia el primer eslabón de la cadena de coros gloriosos que envuelven este núcleo central: la Santa Parentela (fig. 3). Por detrás del Bautista, primo carnal de Cristo, van ocupando su lugar San José, los padres del Bautista: Santa Isabel y San Zacarías y los padres de María: San Joaquín y Santa Ana. San José, destacado discretamente tras el Bautista, viste a la manera tradicional con túnica y manto llevando la clásica rama florecida; dirige su mirada hacia al grupo de la parentela, un tanto ausente de lo que acontece, como tratando de llamarles su atención. Se suceden, por este orden, Santa Ana detrás de San José, vestida como una mujer en edad avanzada y con su característico manto, San Zacarías, ataviado con una fantasiosa muceta con la que se ha tratado de expresar su condición sacerdotal, el cual parece prestar atención a las indicaciones de San José, Santa Isabel, como una anciana mellada, y San Joaquín, situado en el extremo y sin atender a lo que le dice Santa Isabel. Es curioso que este grupo de la parentela de Cristo no haya sido mencionado por Palomino en su proyecto. Como éste son muchos los detalles que debieron resolverse a posteriori y probablemente bajo la supervisión de un teólogo.

II.- Reina de los Ángeles. Los grupos angélicos son también indispensables en toda visión celeste barroca como la presente (fig. 4). Los ángeles no sólo conforman coros caracterizados sino que figurados como criaturas de toda "edad" comprendida entre la niñez y la adolescencia, se introducen entre las nubes como sustentores de éstas o de los santos que las remontan, e incluso se convierten en tenantes de los atributos de éstos: el arpa del rey David, el cántaro de Gedeón o los símbolos de las renuncias terrenas de San Francisco de Borja. En el cenit de la bóveda se descuelga un pequeño grupo, y uno de ellos simula portar la cuerda de la lámpara que cuelga desde este punto, como si el artista hubiera querido significar el origen celeste de la luz de la lámpara; algo más abajo, como turiferario, otro lleva un incensario y otro un manojo de flores en sus dos manos que dirige hacia la Virgen. Al fondo, en la lejanía, se dispone un coro con ángeles adoradores, cantores y músicos portando instrumentos tales como un órgano, una viola y flautas diversas.

III.- Reina de los Patriarcas y Reina de los Profetas. Bajo estos dos enunciados de la Letanía Lauretana, se reúne una gran multitud de personajes vetero-testamentarios que se extiende, formando diferentes grupos, por el sector opuesto al Trono de Gracia, y colocados en diferentes grados de lejanía. Es el sector más complejo de la bóveda desde el punto de vista iconográfico, ya que son pocos los tipos del Antiguo Testamento que poseen tradición iconográfica codificada, lo que hace que no puedan ser identificados con exactitud muchos personajes. De izquierda a derecha, el primer grupo lo forman Adán y Eva, ella con la fruta prohibida en su mano, más otro muchacho detrás de ambos, con las manos juntas, que podría ser Abel; montan una nube que se prolonga hacia la profundidad y en la que se alinea una muchedumbre de bienaventurados. Debajo se nos aproxima un gran grupo en el cual se disponen personajes de muy diversa localización bíblica, aunque en un sentido general correspondería al grupo de los Patriarcas (fig. 5). El primero de ellos, a la izquierda, es el profeta Jeremías, que aparece lloroso, secándose las lágrimas con un paño, algo muy significativo puesto que es el profeta de las Lamentaciones ante la ruina de Jerusalén: 


\author{
“¡Clama, pues, al Señor, \\ gime, oh hija de Sión; \\ deja correr a torrentes tus lágrimas, \\ durante día y noche; \\ no te concedas tregua, \\ ni cese la niña de tu ojo!"'11
}

La tradición asocia a Jeremías estas lamentaciones, y es por otro lado, el profeta de la Pasión de Cristo. Es significativo, en tal sentido, que vista con manto rojo. A las Lamentaciones aludiría, sin duda, el fragmento de rollo con escritura que ha dejado caer a su lado. No resulta claro el personaje situado a su lado que apoya la mano izquierda en un bastón, pero podría tratarse del patriarca Abraham, el gran padre del pueblo de Israel, quien parece escuchar y participar con el profeta de sus tristezas. A continuación Jacob es perfectamente reconocible por la escalera (fig. 6) y encima suyo Noé, con el arca, y el joven Isaac con su haz de leña. Este grupo de los Patriarcas, en su sentido estricto, se completa con otros tres personajes que conversan, dos de ellos de espaldas, y que no son ya reconocibles.

La misma nube recoge a continuación otro grupo de personajes. Entre ellos, destaca Gedeón, con indumentaria militar, en cuyo escudo aparece un enigmático pan, que podría hacer alusión al trabajo que realizaba antes de ser llamado por Yavéh a convertirse en caudillo de Israel. En efecto, Gedeón majaba trigo en el lagar para ocultárselo a los madianitas cuando se le apareció el ángel de Yavéh (Jueces 6, 11). Abimelec, hijo de Gedeón, podría ser el personaje situado detrás de éste, también con indumentaria militar, pero no caracterizado por ningún otro atributo, lo que deja también abierta la posibilidad de tratarse de otro personaje, como Jefté, sucesor de Abimelec como Juez de Israel. Debajo de Gedeón un angelillo porta un cántaro roto con una antorcha encendida en su interior, en alusión a su victoria contra los madianitas, en la cual los soldados rompen los cántaros para retirar las antorchas (Jue. 7, 16-25).

Sansón, considerado por los mitologistas un héroe solar, puesto que su nombre en hebreo significa "pequeño sol" u "hombre del sol", es el guerrero que aparece en el otro extremo de la nube. Lleva un sol en su escudo y la cabeza de un león en una de sus hombreras, como el Herakles cristiano. Sansón está caracterizado además por su típica melena leonina, que asoma debajo del yelmo y que le distingue del resto de personajes. Como se sabe, era en su cabellera donde residía su fuerza, como la del sol en sus rayos ${ }^{12}$.

En medio de todos estos guerreros contrasta la figura de un hombre con el torso desnudo que hace ademán de cubrirse con un manto. Se trata sin ninguna duda de Job. Según el relato bíblico era un hombre rico y feliz, y Dios permitió a Satán que lo probara para ver si seguía siendo fiel en el infortunio, como así fue. Su desnudez es el atributo que mejor lo identifica:

"Desnudo salí del seno de mi madre,

Desnudo allá retornaré.

Yavéh dio, Yavéh quitó:

¡Sea bendito el nombre de Yavéh!” (Job, 1, 21).

Debajo de él, sobre la nube, un rollo con escritura podría hacer alusión al libro poético de Job, la obra maestra literaria del movimiento de Sabiduría bíblico.

Montado en una nube intermedia, haciendo la transición hacia el grupo de más a la izquierda, asoma Melquisedec, aquel sacerdote que ante Abraham realizó un sacrificio con pan y con vino, elementos que nos presenta sobre una bandeja. Melquisedec parece estar pendiente de la conversación que llevan a cabo los dos

\footnotetext{
11 Lamentaciones $2,18$.

12 Cfr. RÉAu, L., Iconographie de l'Art Chrétien (tr. esp. Iconografía del arte cristiano, Barcelona, 1996), t. 1, vol. 1, p. 279. Este personaje ha sido también identificado como Josué con base al sol que figura en el escudo. Pero esto no es suficiente, ya que Josué no goza de una tradición iconográfica definida. Insisto en su identificación como Sansón.
} 


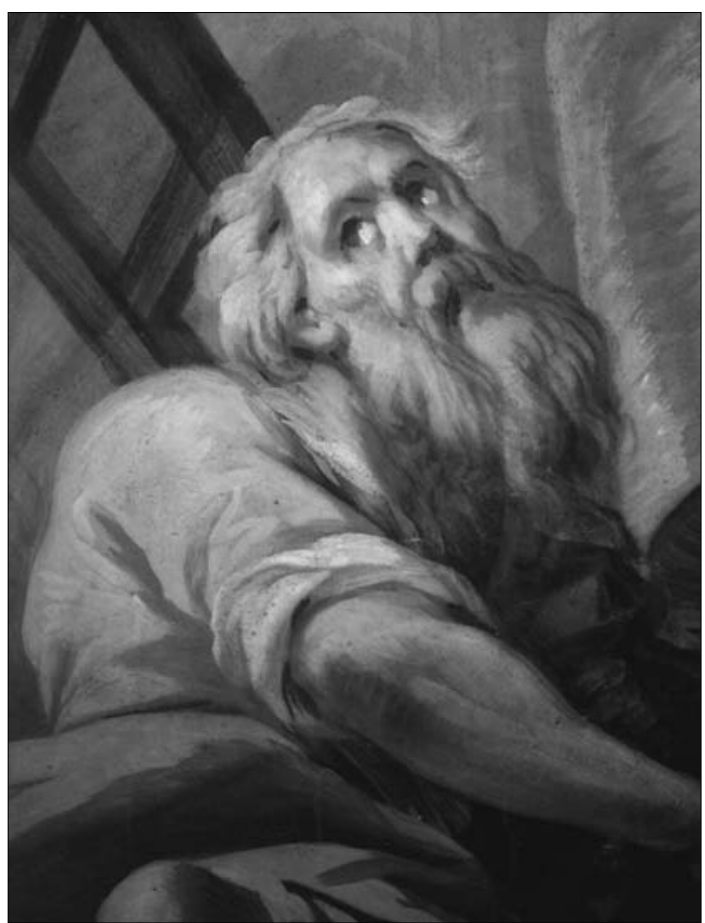

Fig. 6. Jacob.

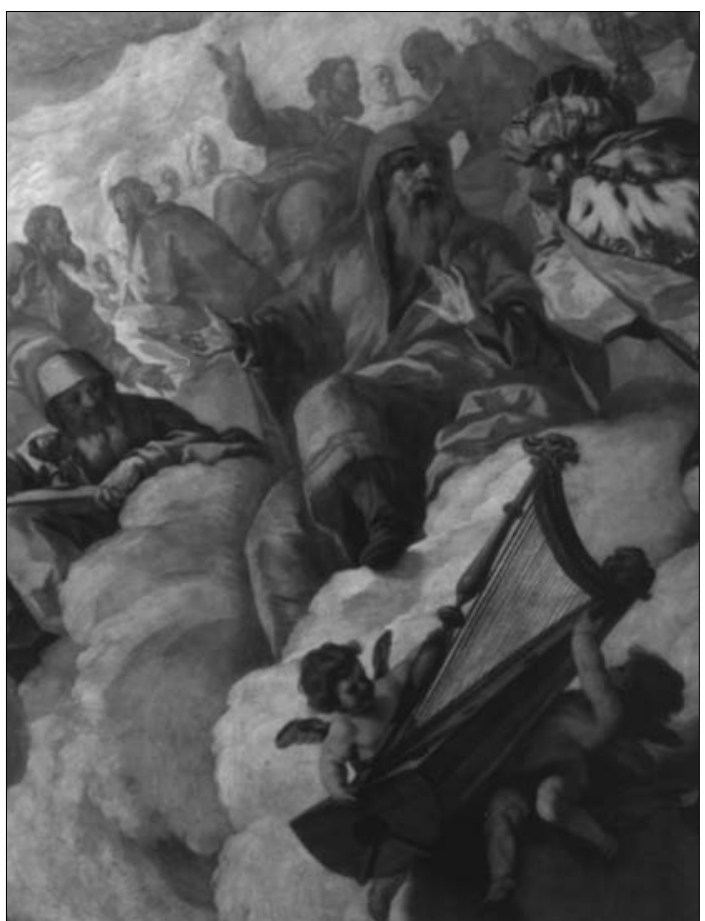

Fig. 7. Melquisedec, Isaías y David.

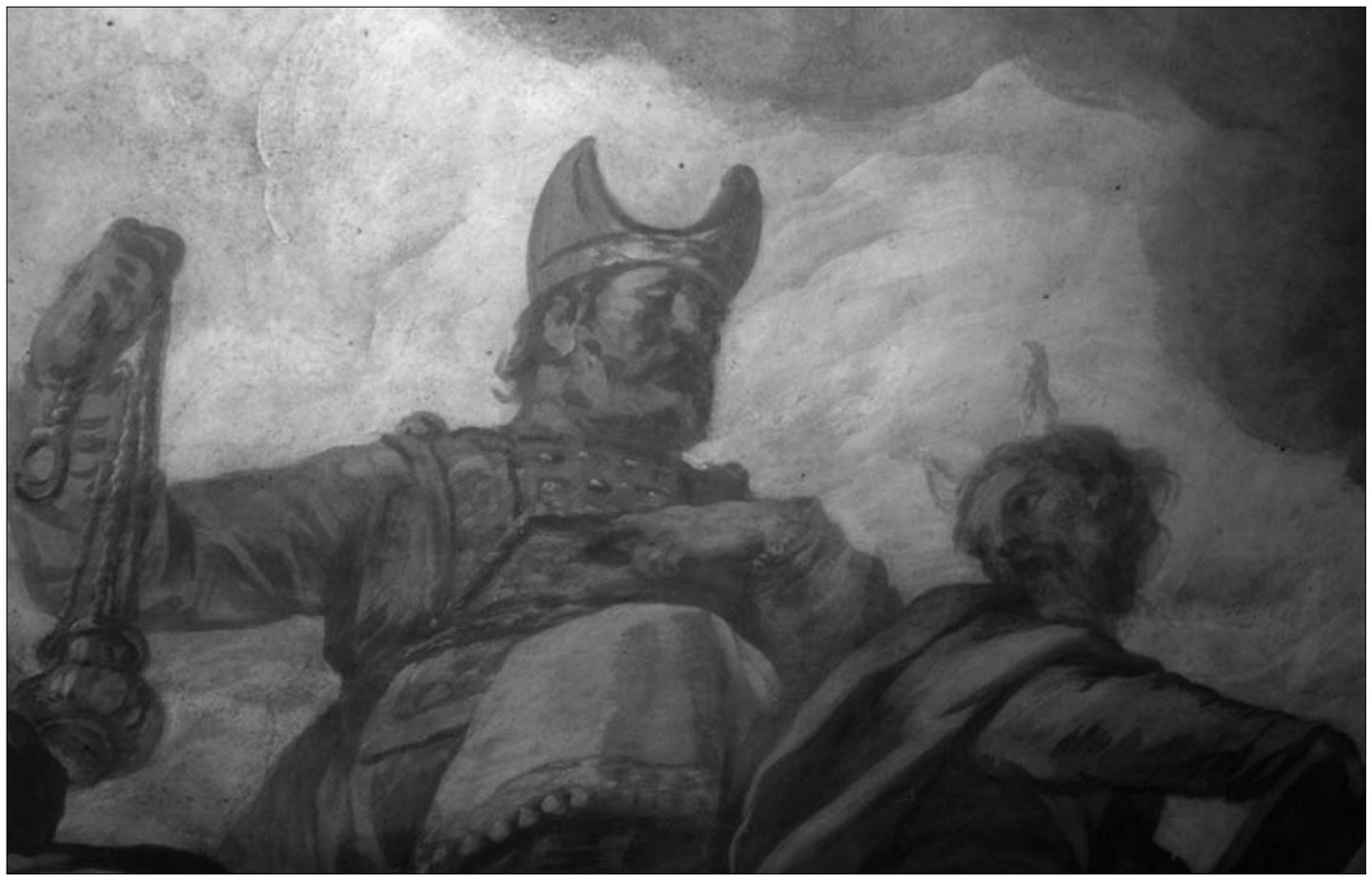

Fig. 8. Aarón y Moisés.

AEA, LXXX, 317, ENERO-MARZO 2007, 67-83, ISSN: 0004-0428 
personajes que tiene a su izquierda, situados en primer término y presentados con toda solemnidad: el rey David y el profeta Isaías (fig. 7). El primero, una de las realizaciones más soberbias de Palomino en esta bóveda, aparece perfectamente caracterizado: viste los ropajes de la realeza y debajo de él unos putti sostienen con gran esfuerzo la pesada arpa que la tradición ha convertido en su atributo genuino. Sobre Isaías, aunque no va caracterizado de modo específico, no caben dudas respecto de su identidad, puesto que no puede faltar en un contexto como el presente. Isaías es el profeta mesiánico por excelencia, en cuyos escritos está presente de manera explícita la Virgen María:

"He aquí que la Virgen concebirá y dará a luz un hijo, y le pondrá por nombre Emmanuel. (Is. 7, 14)"

De acuerdo con los Padres de la Iglesia, María está leyendo este versículo cuando se le apareció el arcángel Gabriel. El profeta viste un manto azul, el color de la Virgen, algo que no parece casual, como tampoco el hecho de que el mismísimo rey David se incline reverente ante sus palabras. Éste parece escuchar otro aspecto importante de estas profecías:

"Y saldrá un vástago del tronco de Jesé y de su raíz se elevará una flor (...)" (Is. 11, 1)

En efecto, Isaías anunció que el Mesías surgiría de la estirpe de David. El árbol de Jesé, como es sabido, es también un tema que la tradición asocia con María, constituyéndose en un tipo iconográfico propio de la Virgen. Es incluso en este contexto como cabe también entender la presencia de Melquisedec, cuyo sacrificio de pan y vino prefigura la presencia sacramental de Cristo.

Por detrás una gran multitud va difuminándose hacia el fondo y en donde aún aparecen bien caracterizados Moisés y Aarón (fig. 8). El primero porta las tablas de la Antigua Ley y desde su frente irradian los rayos de la inspiración divina. Aarón viste los ornamentos del sacerdocio y agita un incensario.

Por último, resta un grupo de dieciséis personajes que ocupan un segundo término sobre una nube más alejada y que podría tratarse de los Profetas en sentido propio (fig. 9), aunque ya hemos apuntado que la distinción entre Patriarcas y Profetas no ha sido establecida de modo tajante en la realidad del presente programa pictórico. Aquí, habría que poner de manifiesto, en primer lugar, el hecho de que este grupo se constituya en número de dieciséis. Se trata evidentemente de un número simbólico, o mejor, retórico. Dieciséis son en realidad el número de profetas de acuerdo con la tradición bíblica católica, los cuales se dividen en dos grupos, en primer lugar los cuatro mayores: Isaías, Jeremías, Ezequiel y Daniel; más los doce menores: Abdías, Ageo, Amós, Habacuc, Joel, Jonás, Malaquías, Miqueas, Nahum, Oseas, Sofonías y Zacarías. Todos tienen en común haber dejado escritos. La distinción entre un grupo y otro no es otra que la cantidad de estos escritos: los profetas mayores han proyectado más escritura. Pero de este conjunto de dieciséis, dos de ellos, Isaías y Jeremías, ya los hemos visto dispuestos fuera de este grupo. Por otro lado, debe ser tenido también en cuenta que existen otros profetas, como Natán, Elías o Eliseo, no enmarcados entre los dieciséis porque no dejaron escritos; son profetas de la acción, como también lo fue Débora. Vemos pues que el número de dieciséis volvería a tener sentido si contamos con alguno de estos últimos. No obstante, como ya he dicho, se trata de un número simbólico que, también, de acuerdo con la tradición tipológica, correspondería con el número de los apóstoles sumándole el de los evangelistas -prescindamos de que dos evangelistas, Mateo y Juan, son además apóstoles-. Los profetas del Antiguo Testamento gozan de tradición iconográfica de forma individual, con atributos característicos, aunque las representaciones son muy escasas, por lo que casi podría decirse que prácticamente no tienen tradición convencionalizada. En el caso presente, Palomino ha obviado su individualización.

IV.- Reina de los Apóstoles. En el tradicional contexto de la Parusía o del Juicio Final, cuando éste se constituyó en el imaginario de la Iglesia, plenamente configurado ya en el Románico, figuraban a modo de asistentes o asesores de Cristo Juez, los veinticuatro ancianos, de acuerdo con la primera fuente que organiza este tipo iconográfico: el Apocalipsis. Pero desde el Gótico, la fuente que inspiró la escena del Juicio fue el Evangelio de San Mateo (Mat. 25, 31 y ss.), lo que conllevó que se prescindiera de los ancianos, siendo éstos substituidos por los apóstoles. Es por ello que se explique el hecho de que aparezcan distribuidos en dos grupos a cada uno de los lados en torno a la Sedes Gratiae ocupada por la Trinidad. El artista aquí no ha querido ser demasiado explícito y, aunque la mayoría de éstos pueden ser identificados por medio de atributos convencionales, otros no son identificables, perdiéndose su individualidad en el conjunto. 

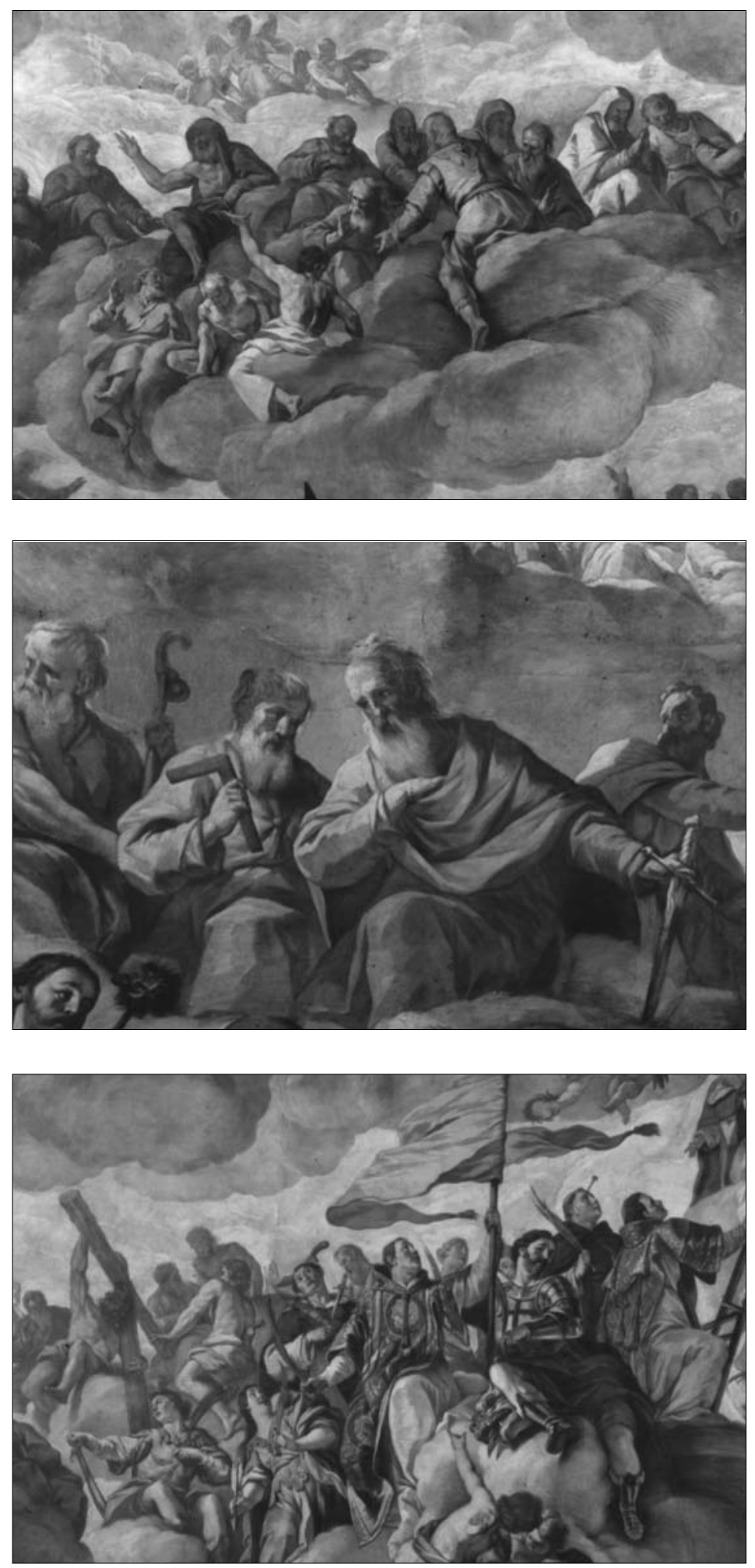

Fig. 9. Los Profetas.

Fig. 10. Santiago el Mayor, Tomás, Pablo y Matías.

Fig. 11. Los Mártires.

AEA, LXXX, 317, ENERO-MARZO 2007, 67-83, ISSN: 0004-0428 
Con Pablo, el Apóstol de los Gentiles, y con Matías, sustituto de Judas Iscariote, conforman un grupo de trece hombres. Por la derecha, desde el centro hacia afuera, arrancan desde la lejanía siete apóstoles. Los dos primeros aparecen conversando: el primero, sin caracterización, podría ser Santiago Alfeo, y Bartolomé, inconfundible por el cuchillo. Siguen otros dos: Simón Zelotes a quien distinguimos por la sierra de su martirio, levemente visible en su mano izquierda, y Felipe, caracterizado con una cruz en asta. Ya situado en la fila delantera (fig. 10) se nos muestra Santiago el Mayor, con indumentaria de peregrino: la concha y el bordón -que R. Stoltz reintegró libremente transformándolo en un cayado pastoril con calabacita-, a continuación Tomás, con una escuadra ya que fue arquitecto, conversa con Pablo, que apoya su mano izquierda en una espada. Cierra el grupo Matías llevando la lanza.

En el lado opuesto se distinguen cinco apóstoles, los cuales se nos muestran en una actitud más contemplativa: el más alejado visualmente, y más próximo al centro, asomando por el fondo y absorto ante la visión de la Trinidad (vid. fig. 2), aunque no caracterizado, puede que se trate de Judas Tadeo. También se vuelve, como extasiado, Juan Evangelista, sostenido en el aire entre una nube y su emblemática águila, y llevando en sus manos libro y pluma. A continuación se suceden Andrés, apoyando su cruz en aspa, San Mateo con el humilde gesto de juntar las manos, y Pedro, inconfundible por las llaves, de las cuales parece olvidarse ante la visión del Trono de Gracia.

V.- Reina de los Mártires. Los mártires ocupan el lugar contiguo a las vírgenes (fig. 11). Conforman un coro abanderado por San Esteban que vestido con su dalmática sostiene una gran bandera roja rematada por la cruz. A su lado, y en primer término San Jorge adquiere gran protagonismo; tiene debajo al dragón abatido. San Lorenzo, sosteniendo su gran parrilla dirige su atención a la Trinidad, al igual que San Bernardo de Alzira (fig. 12), que aparece detrás de él con el hábito blanco, escapulario y capuchón negros de la orden del Císter, con la capa negra de los conversos y caracterizado con el clavo de su martirio hundido en la frente. Por detrás, confundidas entre la multitud, dos cabezas femeninas pueden aludir a sus hermanas María y Gracia $^{13}$. Más allá emerge el dominico San Pedro de Verona (fig. 14) con un cuchillo en medio de la cabeza, un puñal en su corazón y con una palma circundada de tres coronas.

En una vaguada de la nube, en el punto de iniciarse la fuga de ésta hacia el fondo, descuella un mancebo joven, ataviado como soldado, apoyando su mano en una espada, así como una muchacha con rico atuendo llevando una flecha. Ambos llevan también palma de martirio. Se trata de San Mauricio -o bien San Acacio- y de Santa Úrsula. Ambos tienen en común encabezar sendos grupos multitudinarios de mártires: San Mauricio, oficial al mando de la legión tebana, en el s. III, diezmada por orden de Maximiano ${ }^{14}$, y Úrsula, que ofrecería idéntico ejemplo femenino, con sus once mil vírgenes martirizadas por los hunos ${ }^{15}$.

13 Hijo de padre moro, el señor de Carlet, se convirtió al cristianismo y fue monje cisterciense del Monasterio de Poblet. Vuelve a tierras valencianas (1181) predicando el cristianismo y gana a sus hermanas Zaida y Zoraida, que serán bautizadas con los nombres de María y Gracia. Perseguidos por su hermano Al-Mansur, que heredó el señorío de su padre, fueron alcanzados cerca de Alzira. Por su fidelidad al Evangelio, a Bernardo se le metió un clavo de los que usaban para amarrar las barcas en el río Júcar y María y Gracia serán degolladas. Cfr. LEONARDI, C., et al., Il grande libro dei santi, Milán, 1998 (ed. esp. Diccionario de los Santos, Madrid, 2000), vol. I, pp. 373-4.

14 Durante esta prueba, Mauricio supo animar a sus compañeros a la resistencia y al martirio. Además de éste conocemos los nombres de dos oficiales: Exuperio y Cándido, así como el de un veterano: Víctor, que preguntando por las razones de la masacre fue también condenado a muerte por ser cristiano. Cfr. LEONARDI, C., op. cit, vol. II, pp. 1702-4. Mauricio fue un santo celebrado en España, recuérdese el célebre cuadro de El Greco alusivo a su martirio destinado en su origen a una capilla del Monasterio de el Escorial. Siguiendo los mismos planteamientos, también cae dentro de las posibilidades que en lugar de San Mauricio, esta imagen corresponda a San Acacio de Armenia quien, según el relato de una legendaria passio latina -calcada, al parecer de la passio de San Mauricio-, habría éste sido también un oficial romano, primericius de un ejército de diez mil hombres que sufrieron martirio pese a haber logrado, como cristianos, una milagrosa victoria junto al monte Ararat para el propio emperador, quien luego se convierte en su verdugo. Cfr. así mismo LEONARDI, C., op. cit., vol. I, pp. 53-54. La leyenda de San Acacio se popularizó enormemente en centroeuropa, y como ejemplos de su iconografía tenemos un retablo de Bachiacca (s. XVI) conservado en los Ufizzi de Florencia, así como un gran cuadro de Durero conservado en el Museo de Viena.

15 Cfr. Reau, L., op. cit., t. 2 vol. 3, pp 300 y ss., y LeONARDI, op. cit., vol 2, pp. 2163 y ss. 

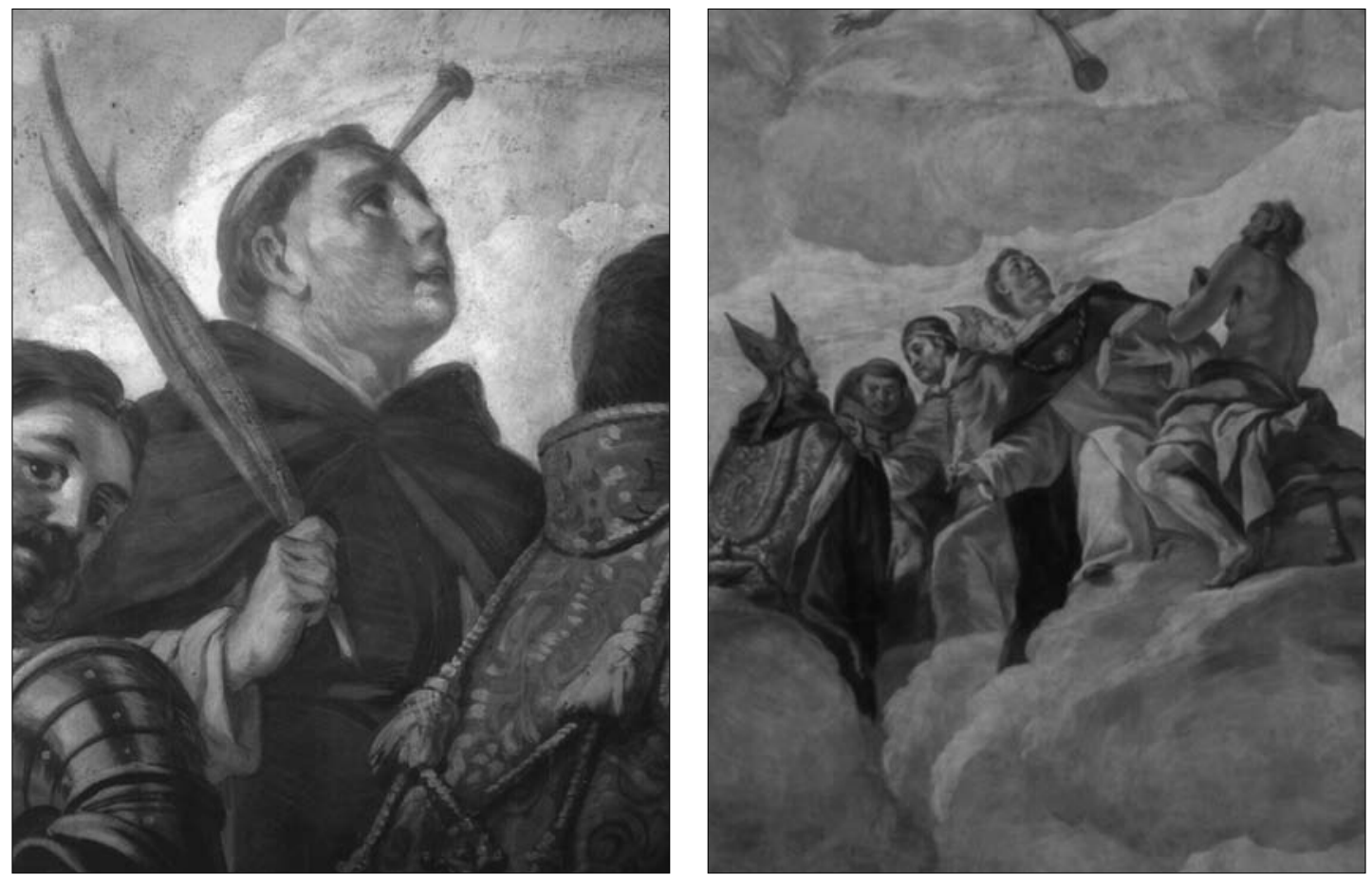

Fig. 12. San Bernardo de Alzira.

Fig. 13. Los Doctores de la Iglesia.

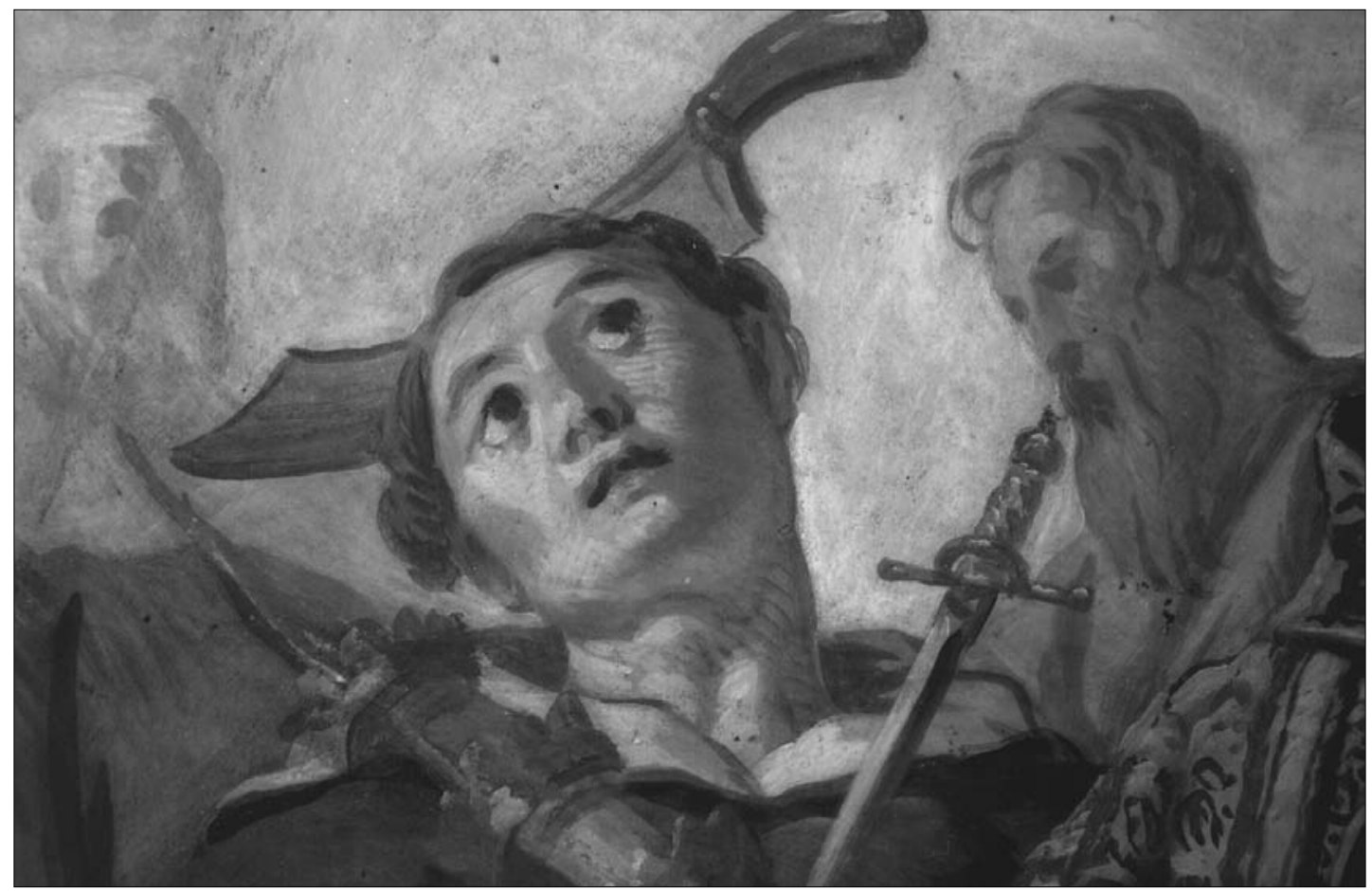

Fig. 14. San Pedro de Verona.

AEA, LXXX, 317, ENERO-MARZO 2007, 67-83, ISSN: 0004-0428 
A partir de aquí, la nube va progresivamente hundiéndose en la lejanía llevando consigo la multitud de mártires, no identificables ya, aunque caracterizados con algunos suplicios: uno de ellos nos da la espalda mostrando un cuchillo hundido, otro levanta una gran cruz donde se supone debió ser también clavado, que nos hace pensar en San Dimas, o el Buen Ladrón ${ }^{16}$. En su conjunto, se trataría de los innumerables mártires que tuvo la Iglesia en época de las persecuciones de los que en su mayor parte no se ha conservado ni siquiera su nombre.

VI.- Reina de los Confesores. La tradición de la Iglesia reconoció la santidad de los mártires en primer lugar, ya que éstos habían sido los "testigos" de Cristo que habían vertido su sangre por la fe. Pero más tarde, a partir del S. IV, cuando los mártires fueron escaseando, engrosarían estas filas los obispos y ascetas, así como las vírgenes, los cuales habían permanecido fieles a lo largo de su vida, a la Ley divina. Los santos no mártires fueron también por tanto "testigos de Cristo" a su manera. Obviamente la Iglesia dispone en primer término el martirio rojo de los mártires, pero considera también el martirio blanco de los confesores y de las Vírgenes.

Entre los confesores, un lugar preeminente lo ocupan los anacoretas, los padres del desierto, abundantes en Egipto y Siria durante los primeros siglos tras la Paz de la Iglesia en el S. IV. Los anacoretas, por otro lado, son el embrión del futuro movimiento monacal. Es significativo que tres destacados anacoretas de la Tebaida, como ancianos barbados, ocupen su lugar como continuación de la hilera de los apóstoles. De este modo, tras la figura de San Pedro se suceden: San Antonio Abad, con cayado y hábito de los monjes de su orden, los antoninos, caracterizado por un sayal con capucha y con la Tau en azul bordada sobre su hombro; San Pablo ermitaño, con el torso desnudo y vestido con malla de hoja de palma y San Onofre, con gesto de sumisión piadosa y con la cintura ceñida con una fronda de zarzal, su atributo iconográfico más individualizado, así como, colgando de sus manos, el salterio o camándula de cuentas rematada con una cruz, objeto semejante al rosario, pero típico de los anacoretas. Este grupo surge de la profundidad en un espacio donde las figuras comienzan a tomar unos perfiles que permiten la distinción individualizada y se nos hace visible por encima del coro de las vírgenes.

El grupo que sigue al de los anacoretas, lo conforman otros santos, en su mayor parte en relación con las diferentes órdenes religiosas (fig. 15). Un poco más cercanos al espectador, en un grado de profundidad intermedia, y formando un grupo aislado, se muestran los dos santos fundadores de la orden trinitaria: San Juan de Mata y San Félix de Valois. Ambos van tonsurados, con una larga barba y visten el hábito blanco de la orden con la cruz de Malta de los trinitarios - palo horizontal azul y el vertical rojo- en el centro del escapulario y con un manto negro con capuchón. Aparecen conversando y uno de ellos, puesto que no se los distingue, porta en su mano izquierda un grillete, en alusión a la redención de cautivos, singularidad de esta orden. Otro grupo más numeroso cabalga otra nube situada encima formando una combada hilera cuyos extremos se prolongan en la profundidad. En el punto más cercano al espectador aparecen enfrentados San Francisco de Asís y Santo Domingo de Guzmán, ataviados cada uno de ellos con los hábitos correspondientes a sus órdenes. San Francisco besa una austera cruz de palo y en sus manos se aprecian los estigmas. Santo Domingo acerca una azucena a su pecho con una mano, mientras que con la otra porta el bordón de fundador que llega a ocultarse por detrás de San Francisco. En el lado de éste último vemos a San Nicolás de Bari, revestido con ornamentos episcopales orientales, aunque no porta mitra, pero sí las tres bolas de oro sobre un libro, atributo tradicional, alusivo a tres dotes que dio a tres hermanas para que éstas pudieran contraer matrimonio. Gesticula con su mano izquierda, como admirado por la visión del Trono de Gracia. Por

16 No puede resultar descabellado, ya que este santo fue venerado en una capilla de la catedral de Valencia y llegó a ser titular de la capilla desde el s. XVIII -antes había sido dedicada por el obispo A. Albalat al Cristo del Salvador-. Vid. SANChis SiverA, J., La Catedral de Valencia. Guía histórica y artística, Valencia, 1909, pp. 314-315. San Dimas es el "Buen Ladrón" crucificado junto a Cristo, a quien según el Evangelio, el mismo Salvador le prometió el paraíso. Una tabla de Miguel Esteve estuvo en esta capilla de la catedral desde el siglo XVI, la cual, tras variada fortuna a lo largo del tiempo ha sido recientemente colocada en dicha capilla que preside hoy el Cristo de la Buena Muerte. La iconografía de esta tabla acaba de ser estudiada por José Mir CuÑAT, "San Dimas y el donante", en Ars Longa, Valencia, 2003, $\mathrm{n}^{\circ} 12$, pp. 33 y ss. 


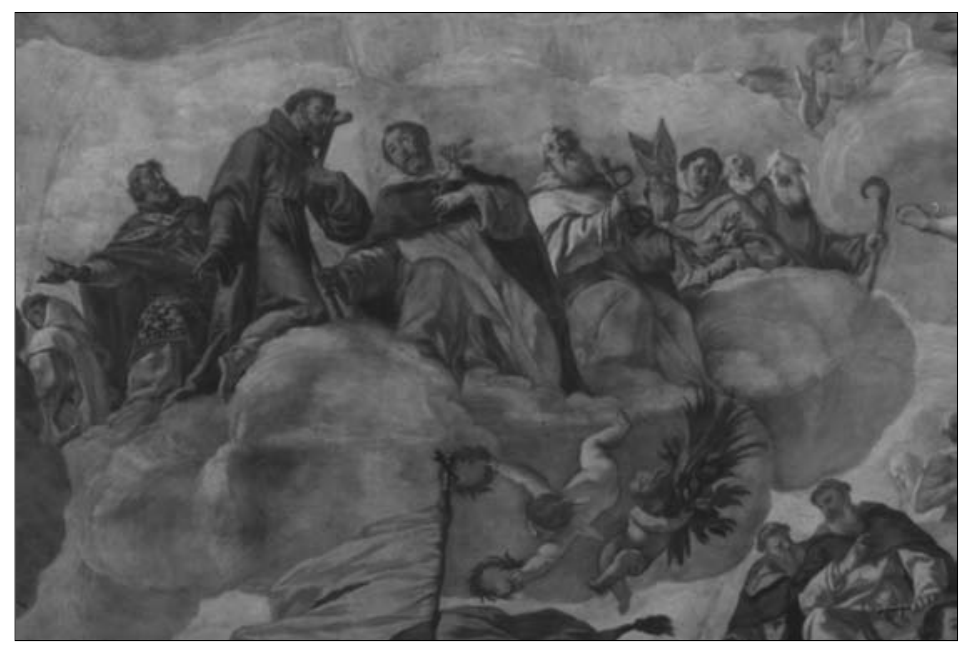

Fig. 15. Los Confesores.

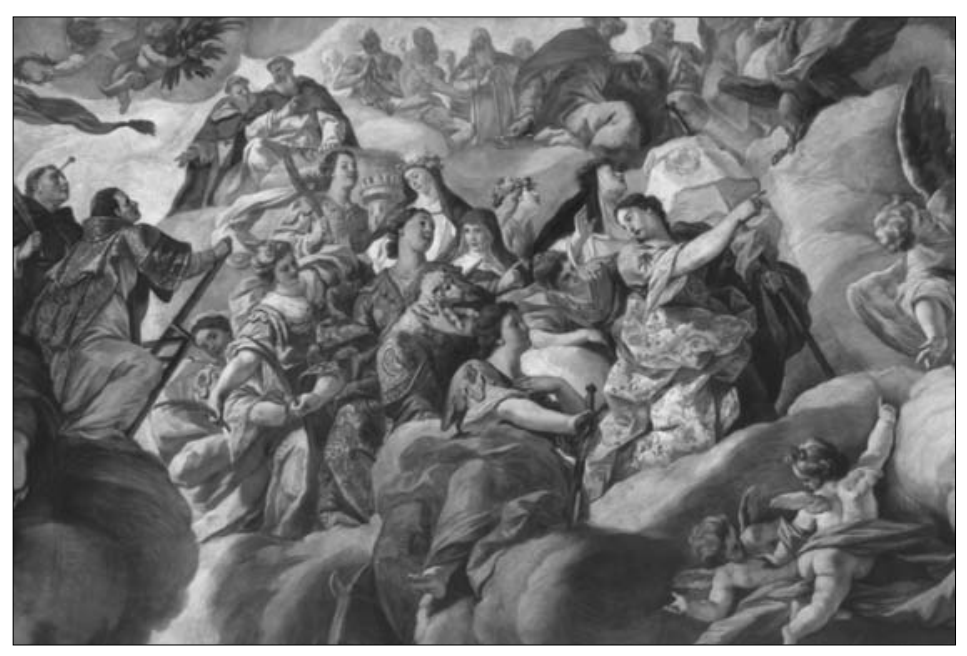

Fig. 16. Las Vírgenes

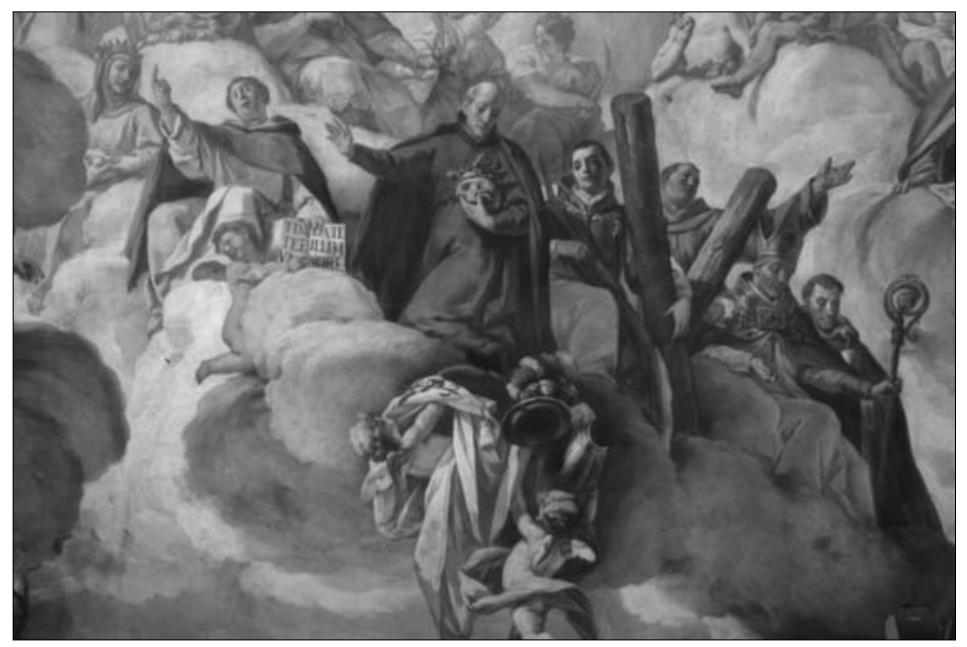

Fig. 17. Los Santos valencianos.

AEA, LXXX, 317, ENERO-MARZO 2007, 67-83, ISSN: 0004-0428 
detrás suyo, como queriéndose recluir, advertimos aún en meditación a San Bruno, fundador de los cartujos, inconfundible por su hábito caracterizado por la cogulla con trabas -equivalente al escapulario en otros hábitos- y sin ningún otro atributo, como queriendo permanecer en el anonimato. Con este recurso Palomino ha querido subrayar la soledad y humildad profesadas por los monjes de esta orden. En el sector de nube que se aleja por detrás de Santo Domingo encontramos a San Pedro Nolasco, fundador de la Merced, vistiendo el hábito blanco de la orden, y exhibiendo también un grillete como redentor de cautivos. Detrás de éste aparecen cuatro figuras, entre las cuales descuella San Antonio de Padua, con hábito franciscano, imberbe y con su azucena, junto con San Francisco de Paula, fundador de la congregación de los Mínimos, con luenga barba y con el bastón curvado, típicos de su iconografía.

Completa este panorama de los santos confesores un grupo muy destacado que reúne a los Doctores de la Iglesia (fig. 13). Allí está San Jerónimo, con su moderna caracterización de penitente, habiéndose despojado de las ropas cardenalicias: un gran manteo de color púrpura, entre cuyos pliegues aún asoma el capelo, envuelve su desnudez. Casi nos da la espalda y aparece frente a Santo Tomás de Aquino, que luce el sol en su pecho, a modo de collar. San Gregorio Magno, vestido con muceta roja y camauro, discute con San Agustín, con capa pluvial, bajo la cual asoma aún el hábito negro de los agustinos. Entre ambos se aprecia la cabeza tonsurada de San Buenaventura, vestido con hábito franciscano y llevando el capelo rojo por detrás de su cabeza, sujeto al cuello por delante. Por detrás del grupo asoma una cabeza mitrada, que permanece ajena a la conversación; quizás se trate de San Ambrosio.

VII.- Reina de las Vírgenes. El coro de vírgenes (fig. 16) aparece inmediatamente a continuación de la primera de ellas: María. Encabeza el grupo Santa Margarita, portadora de la cruz, su atributo característico, en cuya larga asta se enrosca un gran pendón blanco, el color del "martirio blanco" de las Vírgenes, que lleva el emblema de una corona de espinas en torno a un corazón en llamas, símbolo del amor ardiente a Jesucristo, aunque prácticamente todas las que aquí aparecen sufrieron además el "martirio rojo" con el derramamiento de su sangre. Santa Margarita se dirige al grupo señalando mediante un gesto a María ${ }^{17}$. La siguen Santa Catalina de Siena, dominica, coronada de espinas, Santa Teresa de Jesús, carmelita, Santa Rosa de Lima, terciaria dominica, con corona de rosas, como también Santa Rosalía de Palermo, anacoreta. No faltan Santa Bárbara, inconfundible por la torre y la palma del martirio, así como Santa Inés que acaricia el cordero, Santa Catalina de Alejandría, bajo la cual sobresale, en la nube, la rueda dentada de su martirio.

Descuellan también en este grupo otras tres vírgenes de dudosa identificación, ya que su único atributo es la palma del martirio. Podría tratarse de otras vírgenes mártires como Santa Cristina, Santa Águeda, Santa Lucía, Santa Dorotea... No sabemos hasta qué punto Palomino, o sus mentores, pensarían en santas concretas o bien las introducirían para crear la sensación de una multitud, cosa bien probable a juzgar por el carácter que tiene esta representación del cielo y a lo que ya nos hemos referido.

17 Debido al mínimo equipaje de atributos con que Palomino suele desenvolverse, esta figura ha sido anteriormente identificada con Santa Úrsula, quizás debido a que en la iconografía valenciana suele llevar un estandarte, pero en realidad no debe ser considerado éste su atributo principal y más característico. Santa Úrsula, por otro lado, la vemos perfectamente caracterizada en el grupo de mártires haciendo pendant con San Mauricio (vid. supra). Santa Margarita tiene como atributos más frecuentes una cruz, un dragón en cuyas fauces hunde el asta de la cruz, o bien simplemente está bajo sus pies, así como la palma del martirio. Palomino reduce toda caracterización a la cruz. Ha llegado a nuestros días el retablo de San Dionisio y Santa Margarita, obra de Vicent Macip para la capilla correspondiente en la iglesia de San Juan del Hospital. Aquí la santa está dotada de una larga cruz en asta, semejante a como figura en la presente representación de Palomino. También puede constatarse lo mismo en la Santa Margarita de la Predela de las santas, del museo de BB. AA. de Valencia, atribuida también a Macip. Ambas obras han sido datadas a inicios del S. XVI. Otras razones justificarían también la presencia aquí de Santa Margarita: forma parte del grupo de las Quatuor virgines capitales -con Bárbara, Catalina y Dorotea-, así como de los Catorce intercesores, entre los cuales ocupan lugar destacado: Bárbara, Catalina y Margarita. Vid. Reau, L., op. cit., t. 2, vol. 4, pp. 115, 329 y ss. Por otro lado, Santa Margarita fue una santa con capilla propia en la catedral de Valencia hasta finales del siglo XVIII -la capilla de la girola ocupada hoy por la Virgen del Puig-, y llegó a tener un retablo y frontal pintados por Pere Nicolau en 1400 cuando de esta capilla se hizo cargo como patrono el canónigo Rodrigo de Heredia. Cfr. SANCHIS Sivera, J., op. cit., pp. 310-312. 
VIII.- Reina de Todos los Santos. El broche final lo constituye el conjunto de Todos los Santos, significado particularmente aquí mediante el grupo de santos valencianos (fig. 17), los cuales imponen su inconfundible presencia en medio de todo un conjunto de santos anónimos representados en segundo término que confieren forma al conjunto de "todos los santos" según la letanía. Una nube adelantada en talud nos muestra reunidos a los santos valencianos.

El más destacado de todos ellos es San Francisco de Borja, vestido de jesuita con sotana y manteo, sosteniendo su principal atributo: la calavera coronada; a sus pies dos ángeles mantienen en el aire los símbolos de sus honores temporales a los que renunció: la armadura caballeresca, el hábito de la orden militar de Santiago y el capelo cardenalicio. A su derecha aparece San Vicente Ferrer, con hábito dominico, con su inconfundible gesto de levantar el índice, mientras a su lado un angelito mantiene un libro abierto en donde se lee su lema: TIMETE DEVM ET DATE ILLI HONOREM. A continuación sorprende advertir una santa, que por sus atributos es inconfundible: Santa Isabel de Portugal. Sorprende porque no es valenciana, si bien fue hija de Pedro III el Grande, y es probable que fuera incorporada a este grupo de un modo indefectible por no poseer como alternativa una santa estrictamente valenciana. De todos modos debió de ser en este tiempo una santa bastante popular, ya que fue canonizada en 1626. Viste hábito franciscano —es patrona de la Tercera orden de San Francisco-, va coronada y lleva recogido en el manto un manojo de rosas, de acuerdo con un conocido milagro que consta en su proceso de canonización.

Por la izquierda de San Francisco de Borja se suceden en hilera otros santos valencianos muy conocidos. En primer lugar el patrón de la ciudad San Vicente mártir, vestido con dalmática como diácono, llevando la palma del martirio y sosteniendo con su mano la enorme cruz en aspa de su martirio. Detrás San Pascual Bailón, franciscano descalzo, no adora ya el Sacramento eucarístico sino que con su gesto demuestra el gozo, ya en el cielo, de la visión directa de Dios. A continuación Santo Tomás de Villanueva, con capa pluvial, mitra y báculo, se nos muestra con el gesto caritativo de ofrecer una moneda, y a su lado el dominico San Luis Bertán, el apóstol de Colombia y México, con el atributo de la copa con la serpiente, emblema indicador de que intentaron envenenarle.

Por detrás de esta serie de santos valencianos, en diferente gradación de lejanía, se disponen otros en su mayor parte con identificación confusa, pero que sin duda la intención fue precisamente mantener cierto anonimato para significar la muchedumbre de santos del cielo. No olvidemos que se quiso significar también, con palabras del mismo Palomino, a "todos los Bienaventurados". No obstante hay uno de ellos cuya identificación es segura: San Pedro Pascual, un santo canonizado en 1670 y cinco años más tarde incluido en el Martirologio Romano. Se le representa con hábitos corales, como canónigo de la catedral de Valencia, con palma de martirio y con una espada en alusión a su supuesta decapitación en Granada. Aparecen también dos santas mártires, con sendas palmas, y un grupo de mitrados en torno a un papa que nos es mostrado de espaldas. Podrían ser identificados todos estos personajes, más allá del repertorio valenciano, como las mártires Justa y Rufina, así como los obispos hispalenses San Leandro y San Isidoro y el papa San Dámaso. Incluso podríamos ver en uno de ellos a San Valero, ya que fue obispo y compañero de presidio de San Vicente y cuya devoción está arraigada en Valencia. No obstante preferimos optar por dejar en la indefinición todas estas figuras, y entender su conjunto como multitud de santos, de acuerdo con el programa iconográfico, que expresa claramente la intención de afirmar la muchedumbre de los bienaventurados, dando así forma a aquella expresión letánica de María como "Reina de todos los santos".

AEA, LXXX, 317, ENERO-MARZO 2007, 67-83, ISSN: 0004-0428 